\title{
sciendo
}

Current Issues in Pharmacy and Medical Sciences

Formerly ANNALES UNIVERSITATIS MARIAE CURIE-SKIODOWSKA, SECTIO DDD, PHARMACIA

journal homepage: http://www.curipms.umlub.pl/

\section{Analysis of the phenotypic and genotypic antimicrobial resistance profiles of clinically significant enterococci isolated in the Provincial Specialist Hospital in Lublin, Poland}

\author{
Agnieszka Bogut ${ }^{1 *} \oplus$, Patrycja MroziK ${ }^{1}$, \\ Gabriela Czaja ${ }^{1}$, Malgorzata Stawecka-Hamerla ${ }^{2}$
}

${ }^{1}$ Chair and Department of Medical Microbiology, Medical University of Lublin, Chodzki 1, 20-093 Lublin, Poland

${ }^{2}$ Department of Laboratory Diagnostics, Coagulation and Microbiology, Provincial Specialist Hospital Stefan Cardinal Wyszynski, Lublin, Poland

\section{ARTICLE INFO}

Received 14 July 2021

Accepted 01 September 2021

\section{Keywords:}

Enterococci,

Enterococcus faecium,

antibiotic resistance,

multidrug resistance,

high-level aminoglycoside

resistant enterococci,

vancomycin-resistant

enterococci.

\begin{abstract}
The increasing significance of enterococci as healthcare-associated pathogens can be linked to their limited susceptibility to antibiotics.

In this study, phenotypic and genotypic resistance profiles of 35 [n=18 E. faecium (Efm); $\mathrm{n}=17 \mathrm{E}$. faecalis $(E f s)]$ invasive isolates cultured from hospitalized patients were analysed. Phenotypic identification was verified by the multiplex PCR targeting the 16S rDNA and the $d d l$ genes encoding for the $E f s$ and $E f m$ - specific ligases. Antimicrobial susceptibility was determined using the disc diffusion method and E-tests. The high-level streptomycin resistance (HLSR), high-level gentamicin resistance (HLGR) and glycopeptide resistance was verified by amplification of the ant(6)-Ia, $a a c\left(6^{\prime}\right)-I e-a p h\left(2^{\prime \prime}\right)-I a$, as well as vanA and vanB genes, respectively.

More than $70 \%$ of all isolates were cultured from patients in the Intensive Care and Internal Medicine Units. Blood was the predominant (77\%) site of isolation. All Efm isolates were resistant to ampicillin, imipenem, and norfloxacin; 17 isolates demonstrated high-level aminoglycoside resistance (HLAR), including $27.7 \%$ with HLSR, 38.8\% with HLGR and $27.7 \%$ with both phenotypes. HLAR was also common in Efs (HLSR $>70 \%$, HLGR $>50 \%)$, followed by norfloxacin $(64.7 \%)$ and ampicillin $(11.7 \%)$ resistance. The ant(6)-Ia and aac(6')-Ie-aph(2")-Ia genes were detected in $>90 \%$ of the HLSR and HLGR isolates, respectively. Glycopeptide resistance was detected in 4 (22.2\%) Efm isolates and mediated by the vanA gene. 19 (54.3\%) isolates were multidrug resistant, including 17 (89.5\%) Efm. All isolates were susceptible to linezolid.

The study constitutes a contribution to the analysis of enterococcal antimicrobial resistance in Polish hospitals. The monitoring of enterococcal prevalence and antimicrobial resistance is crucial to control and prevent infections.
\end{abstract}

\section{INTRODUCTION}

Enterococci are common members of the human gastrointestinal microbiota. They represent a group of Gram-positive facultative anaerobes capable of survival in the presence of unfavourable environmental conditions, including high salt concentrations and elevated temperatures [1-3]. These bacteria are also able to resist chemical stress induced by chlorine and alcohol-based disinfectants [4] and quickly adapt to a changing environment [5]. The intrinsic properties

\footnotetext{
* Corresponding author

e-mail: agnieszkabogut@umlub.pl
}

of enterococci confer the ability to resist host defences and to compete in the intestinal tract, which subsequently leads to persistence and spread in the environment, hence favouring colonization of new hosts [6].

In spite of the fact that the inherent virulence potential of enterococci lags behind that of the more pathogenic streptococci, during the past few decades, they have emerged as important healthcare-associated pathogens $[1,4]$. Indeed, enterococci have gained the position of the leading opportunistic pathogens, especially in elderly, multimorbid, critically ill and immunocompromised populations $[1,2,5]$. 
According to Miller et al. [2], in the timeframe between 2015 and 2017, enterococci were reported as the second leading cause of healthcare-associated infections (HAI) overall, including their leading role in the etiology of central line-associated bloodstream infections in long-term acute care hospitals and in oncology units. Infections of enterococcal etiology typically manifest as urinary tract infections, bacteremia, intra-abdominal infections, endocarditis as well as skin, soft tissue infections and device infections [2,6,7]. Their increasing clinical significance can be ascribed to their durable and commensal nature $[2,7]$, but the real challenge that overshadows the treatment is a limited susceptibility to antibiotics, due to both intrinsic and acquired antibiotic resistance [6].

Enterococcus faecalis and Enterococcus faecium represent two most clinically relevant enterococcal species $[7,8]$. They demonstrate intrinsic resistance to cephalosporins, low levels of aminoglycosides, clindamycin and trimethoprimsulfamethoxazole. In addition, due to a remarkably plastic genome, the two species have been able to readily acquire resistance to further antimicrobial agents, including highlevel aminoglycoside resistance (HLAR), high-level ampicillin resistance and vancomycin resistance (vancomycinresistant enterococci, VRE). The acquired resistance phenotypes develop as a result of mutation or a horizontal transfer of genetic elements harboring resistance determinants [7,9]. Moreover, resistance to newer antibiotics, such as daptomycin and oxazolidinones continues to emerge [2,10], with the latest threat and therapeutic dilemma being the multidrugresistant (MDR) E. faecium [4,5]. E. faecium has been classified as one of the microbes that "escape" antibiotic treatment, hence, it has been included in the acronym ESKAPE (Enterococcus faecium, Staphylococcus aureus, Klebsiella pneumoniae, Acinetobacter baumanii, Pseudomonas aeruginosa, Enterobacter spp.) among other important MDR bacteria involved in HAI $[8,11]$.

There have been relatively few literature data raising the problem of enterococcal antibiotic resistance in Poland, with the most recent reports being by Chmielarczyk et al. (2021) [12], Krawczyk et al. (2020) [9], Kamińska et al. (2019) [3], Talaga-Ćwiertnia \& Bulanda (2018) [11], Talaga et al. (2018) [13], and Gawryszewska et al. $(2017,2016)$ [14,15].

\section{AIM}

The aim of the study was to characterize phenotypic and genotypic resistance profiles of 35 invasive enterococcal isolates cultured from patients hospitalized in the Provincial Specialist Hospital in Lublin, Poland.

\section{MATERIALS AND METHODS}

\section{Phenotypic identification of the isolates, antimicrobial susceptibility testing}

The study included 35 clinically significant enterococal isolates collected in the Stefan Kardynał Wyszyński Provincial Specialist Hospital in Lublin, Poland, in the period between October 2020 and March 2021 in passive surveillance. The isolates were cultured from 20 male and 15 female patients (one isolate per patient). The age of patients ranged from 45 to 97 years (mean age: 71.5 years). Information regarding the patients, as well as the types of clinical samples from which enterococci were cultured and hospital wards in which the infected patients were hospitalized are included in Table 1.

Identification of the isolates to the species level was performed in the hospital laboratory using standard microbiological methods, including the BD Phoenix ${ }^{\mathrm{TM}}$ (Becton Dickinson, USA) automatic system. Antimicrobial susceptibility of the isolates was determined using the disc diffusion method and E-tests, and interpreted according to recommendations of the European Committee on the Antibiotic Susceptibility Testing (EUCAST, v.11.0). The susceptibility testing included discs impregnated with ampicillin $(2 \mu \mathrm{g})$, gentamicin $(30 \mu \mathrm{g})$ (Oxoid, England), imipenem (10 $\mu \mathrm{g})$, norfloxacin $(10 \mu \mathrm{g})$, linezolid $(10 \mu \mathrm{g})$, streptomycin $(300$ $\mu \mathrm{g})$, vancomycin $(5 \mu \mathrm{g})$ and teicoplanin $(30 \mu \mathrm{g})$ (Becton, Dickinson and Company, USA), and E-tests containing teicoplanin (0,016-256 mg/L), streptomycin (0,064-1024 $\mathrm{mg} / \mathrm{L})$, gentamicin $(0,016-256 \mathrm{mg} / \mathrm{L})$ and vancomycin (0,016-256 mg/L) (Liofilchem, Italy).

The HLAR phenotype was subcategorized into the highlevel gentamicin resistance (HLGR) and high-level streptomycin resistance (HLSR). The presence of HLGR and HLSR phenotypes was detected using the disc diffusion method, and verified using E-tests. According to the EUCAST recommendations, HLGR is defined if the gentamicin MIC value is $>128 \mathrm{mg} / \mathrm{L}$ or the zone of inhibition around the disc with gentamicin is $<8 \mathrm{~mm}$, while HLSR is defined if the streptomycin MIC value is $>512 \mathrm{mg} / \mathrm{L}$ or the zone of inhibition around the disc with streptomycin is $<14 \mathrm{~mm}$. The HLGR phenotype is consistent with bacterial resistance to all aminoglycosides with the exception of streptomycin and is tantamount to the loss of the synergy between aminoglycosides and beta-lactams or glycopeptides in the therapy. HLSR phenotype is consistent with bacterial resistance to streptomycin and is tantamount to the loss of the synergy between the drug and beta-lactams or glycopeptides in the therapy.

Reference strains represented by E. faecalis ATCC 29212 (wild type, fully susceptible) and E. faecalis ATCC 51299 [HLAR, VRE phenotypes; genotype: $\operatorname{ant}(6)-I$, aac(6') $\operatorname{aph}(2$ '), vanB] were used as quality controls.

\section{Molecular identification of the isolates, detection of antimicrobial resistance genes}

Phenotypic identification of the isolates was verified by the multiplex PCR reaction targeting the $16 \mathrm{~S}$ rDNA region (to serve as a positive control for the amplification of the DNA sample in the PCR reaction) and the $d d l$ genes encoding for the D-Ala:D-Ala ligases specific for E. faecalis and E. faecium ( $\mathrm{ddl}_{\text {E. faecalis }}$ and $\mathrm{ddl}_{\text {E. faecium, }}$ respectively). HLGR was detected by amplification of the aac (6')Ie-aph (2")-Ia gene which encodes a bifunctional aminoglycoside modifying enzyme/AME designated AAC(6')APH(2")-Ia. HLSR was ascertained by amplification of the $\operatorname{ant}(6)-I a$ gene encoding for the monofunctional AME, 6-nucleotidylotransferase I (ANT(6)-I). Vancomycin resistance was established using primers designed to amplify the $v a n A$ and $v a n B$ genes involved in the modification of the 
Table 1. Characterization of enterococcal isolates analysed in the study, including their phenotypic and genotypic antibiotic resistance profiles

\begin{tabular}{|c|c|c|c|c|c|c|}
\hline \begin{tabular}{|c|} 
Patient no. \\
(gender, age) \\
\end{tabular} & $\begin{array}{c}\text { Strain } \\
\text { no. }\end{array}$ & \begin{tabular}{|c|}
$\begin{array}{c}\text { Site of } \\
\text { isolation }\end{array}$ \\
\end{tabular} & Hospital ward & \begin{tabular}{|c|} 
Molecular \\
identification \\
\end{tabular} & $\begin{array}{c}\text { Phenotypic } \\
\text { resistance profile }\end{array}$ & $\begin{array}{c}\text { Genotypic resistance } \\
\text { profile }\end{array}$ \\
\hline 1. $(M, 80)$ & E1 & Blood & Intensive Care Unit & E. faecium & $\begin{array}{c}\text { AMP, IPM, NOR, } \\
\text { HLSR * }\end{array}$ & ant(6)-Ia \\
\hline 2. $(F, 79)$ & E2 & Blood & \begin{tabular}{|c|} 
Allergology and \\
Lung Diseases Unit
\end{tabular} & E. faecalis & NOR, HLSR & ant(6)-Ia \\
\hline 3. $(F, 68)$ & E3 & Urine & $\begin{array}{c}\text { Internal Medicine } \\
\text { Unit }\end{array}$ & E. faecalis & NOR, HLSR, HLGR & $\begin{array}{c}\text { ant }(6)-\mathrm{Ia}, \\
\operatorname{aac}\left(6^{\prime}\right)-\mathrm{Ie}-\operatorname{aph}\left(2^{\prime \prime}\right)-\mathrm{Ia}\end{array}$ \\
\hline 4. $(F, 78)$ & E4 & Blood & $\begin{array}{c}\text { Internal Medicine } \\
\text { Unit }\end{array}$ & E. faecium & $\begin{array}{c}\text { AMP, IPM, NOR, } \\
\text { HLGR * }\end{array}$ & $\operatorname{aac}\left(6^{\prime}\right)-\mathrm{Ie}-\mathrm{aph}\left(2^{\prime \prime}\right)-\mathrm{Ia}$ \\
\hline 5. $(F, 61)$ & E5 & Blood & Intensive Care Unit & E. faecium & $\begin{array}{c}\text { AMP, IPM, NOR, } \\
\text { HLSR * }\end{array}$ & ant(6)-Ia \\
\hline 6. $(F, 68)$ & E6 & Blood & Intensive Care Unit & E. faecium & $\begin{array}{c}\text { AMP, IPM, NOR, } \\
\text { HLSR * }\end{array}$ & ant(6)-Ia \\
\hline 7. $(M, 69)$ & E7 & Urine & $\begin{array}{c}\text { Internal Medicine } \\
\text { Unit }\end{array}$ & E. faecalis & $\begin{array}{c}\text { AMP, NOR, HLSR, } \\
\text { HLGR * }\end{array}$ & $\begin{array}{c}\text { ant(6)-Ia, } \\
\operatorname{aac}\left(6^{\prime}\right)-\mathrm{Ie}-\mathrm{aph}\left(2^{\prime \prime}\right) \text {-Ia }\end{array}$ \\
\hline 8. $(M, 63)$ & E8 & Blood & Nephrology Unit & E. faecium & $\begin{array}{c}\text { AMP, IPM, NOR, } \\
\text { HLSR * }\end{array}$ & ant $(6)-I a$ \\
\hline 9. $(F, 63)$ & E9 & Wound & Surgery Unit & E. faecalis & fully susceptible & - \\
\hline 10. $(M, 45)$ & E10 & Blood & Cardiology Unit & E. faecalis & fully susceptible & - \\
\hline 11. $(M, 40)$ & E11 & Wound & Intensive Care Unit & E. faecium & $\begin{array}{c}\text { AMP, IPM, NOR, } \\
\text { HLSR, HLGR, VA, } \\
\text { TEC * } \\
\end{array}$ & $\begin{array}{c}\text { ant(6)-Ia, } \\
\text { aac(6')-Ie-aph(2")-Ia, } \\
\text { vanA } \\
\end{array}$ \\
\hline 12. $(M, 47)$ & E12 & Blood & Intensive Care Unit & E. faecium & $\begin{array}{c}\text { AMP, IPM, NOR, } \\
\text { HLSR * }\end{array}$ & - \\
\hline 13. $(M, 48)$ & E13 & Blood & Intensive Care Unit & E. faecalis & NOR, HLSR, HLGR & $\begin{array}{c}\text { ant(6)-Ia, } \\
\text { aac(6 (6')-Ie-aph( }\left(2^{\prime \prime}\right)-\mathrm{Ia}\end{array}$ \\
\hline 14. $(F, 76)$ & E14 & Blood & Intensive Care Unit & E. faecium & $\begin{array}{l}\text { AMP, IPM, NOR, } \\
\text { HLGR, VA, TEC } *\end{array}$ & $\begin{array}{c}\operatorname{aac}\left(6^{\prime}\right)-\operatorname{Ie}-a p h\left(2^{\prime \prime}\right)-I a, \\
\text { vanA }\end{array}$ \\
\hline 15. $(M, 65)$ & E15 & Blood & $\begin{array}{c}\text { Internal Medicine } \\
\text { Unit }\end{array}$ & E. faecium & $\begin{array}{l}\text { AMP, IPM, NOR, } \\
\text { HLGR * }\end{array}$ & $\operatorname{aac}\left(6^{\prime}\right)-\mathrm{Ie}-\mathrm{aph}\left(2^{\prime \prime}\right)-\mathrm{Ia}$ \\
\hline 16. $(F, 85)$ & E16 & Blood & $\begin{array}{c}\text { Internal Medicine } \\
\text { Unit }\end{array}$ & E. faecium & $\begin{array}{c}\text { AMP, IPM, NOR, } \\
\text { HLGR * }\end{array}$ & $\operatorname{aac}\left(6^{\prime}\right)-\mathrm{Ie}-\mathrm{aph}\left(2^{\prime \prime}\right)-\mathrm{Ia}$ \\
\hline 17. $(F, 86)$ & E17 & Blood & $\begin{array}{c}\text { Internal Medicine } \\
\text { Unit }\end{array}$ & E. faecium & $\begin{array}{c}\text { AMP, IPM, NOR, } \\
\text { HLSR, HLGR, VA, } \\
\text { TEC * } \\
\end{array}$ & ant(6)-Ia, vanA \\
\hline 18. $(F, 77)$ & E18 & Blood & Intensive Care Unit & E. faecalis & NOR, HLSR, HLGR & $\begin{array}{c}\text { ant(6)-Ia, } \\
\operatorname{aac}\left(6^{\prime}\right)-\mathrm{Ie}-\mathrm{aph}\left(2^{\prime \prime}\right)-\mathrm{Ia}\end{array}$ \\
\hline 19. $(F, 76)$ & E19 & Urine & $\begin{array}{c}\text { Internal Medicine } \\
\text { Unit }\end{array}$ & E. faecium & $\begin{array}{l}\text { AMP, IPM, NOR, } \\
\text { HLSR, HLGR * }\end{array}$ & $\begin{array}{c}\text { ant(6)-Ia, } \\
\text { aac(6 }\left(6^{\prime}\right)-\mathrm{Ie}-\mathrm{aph}\left(2^{\prime \prime}\right)-\mathrm{Ia}\end{array}$ \\
\hline 20. $(M, 74)$ & E20 & Urine & \begin{tabular}{|c|} 
Allergology and \\
Lung Diseases Unit \\
\end{tabular} & E. faecium & $\begin{array}{c}\text { AMP, IPM, NOR, } \\
\text { HLGR * }\end{array}$ & $\operatorname{aac}\left(6^{\prime}\right)-\mathrm{Ie}-\mathrm{aph}\left(2^{\prime \prime}\right)-\mathrm{Ia}$ \\
\hline 21. $(F, 56)$ & E21 & Blood & Intensive Care Unit & E. faecalis & $\begin{array}{l}\text { AMP, IPM, NOR, } \\
\text { HLSR, HLGR * }\end{array}$ & $\begin{array}{c}\text { ant(6)-Ia, } \\
\operatorname{aac}\left(6^{\prime}\right)-\mathrm{Ie}-\mathrm{aph}\left(2^{\prime \prime}\right) \text {-Ia }\end{array}$ \\
\hline 22. $(M, 81)$ & E22 & Blood & Intensive Care Unit & E. faecium & AMP, IPM, NOR & - \\
\hline 23. $(M, 97)$ & E23 & Blood & $\begin{array}{c}\text { Internal Medicine } \\
\text { Unit }\end{array}$ & E. faecium & $\begin{array}{l}\text { AMP, IPM, NOR, } \\
\text { HLSR, HLGR * }\end{array}$ & $\operatorname{aac}\left(6^{\prime}\right)-\mathrm{Ie}-\mathrm{aph}\left(2^{\prime \prime}\right)-\mathrm{Ia}$ \\
\hline 24. $(M, 75)$ & E24 & Blood & \begin{tabular}{|c|} 
Allergology and \\
Lung Diseases Unit
\end{tabular} & E. faecalis & NOR, HLSR & ant(6)-Ia \\
\hline 25. $(F, 78)$ & E25 & Blood & $\begin{array}{c}\text { Internal Medicine } \\
\text { Unit }\end{array}$ & E. faecium & $\begin{array}{c}\text { AMP, IPM, NOR, } \\
\text { HLGR * }\end{array}$ & $\operatorname{aac}\left(6^{\prime}\right)$-Ie-aph $\left(2^{\prime \prime}\right)$-Ia \\
\hline 26. $(M, 91)$ & E26 & Blood & Cardiology Unit & E. faecalis & NOR, HLSR, HLGR & $\begin{array}{c}\text { ant }(6)-\mathrm{Ia} \\
\mathrm{aac}\left(6^{\prime}\right)-\mathrm{Ie}-\mathrm{aph}\left(2^{\prime \prime}\right) \text {-Ia }\end{array}$ \\
\hline 27. $(M, 73)$ & E27 & Blood & $\begin{array}{c}\text { Internal Medicine } \\
\text { Unit }\end{array}$ & E. faecalis & fully susceptible & - \\
\hline 28. $(M, 66)$ & E28 & Blood & \begin{tabular}{|c|} 
Allergology and \\
Lung Diseases Unit \\
\end{tabular} & E. faecalis & NOR, HLSR, HLGR & $\begin{array}{c}\text { ant(6)-Ia, } \\
\operatorname{aac}\left(6^{\prime}\right)-\mathrm{Ie}-\mathrm{aph}\left(2^{\prime \prime}\right)-\mathrm{Ia} \\
\end{array}$ \\
\hline 29. $(M, 75)$ & E29 & Blood & \begin{tabular}{|c|} 
Allergology and \\
Lung Diseases Unit \\
\end{tabular} & E. faecalis & NOR, HLSR & ant(6)-Ia \\
\hline 30. $(M, 86)$ & E30 & Urine & $\begin{array}{c}\text { Internal Medicine } \\
\text { Unit }\end{array}$ & E. faecalis & NOR, HLSR, HLGR & $\begin{array}{c}\text { ant(6)-Ia, } \\
\operatorname{aac}\left(6^{\prime}\right)-\mathrm{Ie}-\mathrm{aph}\left(2^{\prime \prime}\right) \text {-Ia }\end{array}$ \\
\hline 31. $(F, 85)$ & E31 & Blood & $\begin{array}{c}\text { Internal Medicine } \\
\text { Unit } \\
\end{array}$ & E. faecium & $\begin{array}{c}\text { AMP, IPM, NOR, } \\
\text { HLGR * }\end{array}$ & $\operatorname{aac}\left(6^{\prime}\right)-\mathrm{Ie}-\mathrm{aph}\left(2^{\prime \prime}\right)-\mathrm{Ia}$ \\
\hline 32. $(M, 67)$ & E32 & Blood & Intensive Care Unit & E. faecalis & fully susceptible & - \\
\hline 33. $(F, 80)$ & E33 & Urine & $\begin{array}{c}\text { Internal Medicine } \\
\text { Unit }\end{array}$ & E. faecium & $\begin{array}{c}\text { AMP, IPM, NOR, } \\
\text { HLSR, HLGR, VA, } \\
\text { TEC * } \\
\end{array}$ & $\begin{array}{c}\text { ant(6)-Ia } \\
\operatorname{aac}\left(6^{\prime}\right)-\mathrm{Ie}-\mathrm{aph}\left(2^{\prime \prime}\right)-\mathrm{Ia}, \\
\operatorname{vanA}\end{array}$ \\
\hline 34. $(M, 81)$ & E34 & Blood & Nephrology Unit & E. faecalis & HLSR, HLGR & ant(6)-Ia \\
\hline 35. $(M, 66)$ & E35 & Blood & Intensive Care Unit & E. faecalis & fully susceptible & - \\
\hline
\end{tabular}

was then centrifuged for $5 \mathrm{~min}$. at a maximum speed and the supernatant was transferred to a new tube. Primer sequences and amplification conditions used in the PCR assays are shown in Table 2.

The multiplex PCR assay for the identification of the species was performed in a final volume of 25 $\mu l$ containing DNA as template, $0.1 \mu \mathrm{M}$ of each primer, $0.1 \mathrm{mM}$ of dNTPs, 0.625 U of the Taq DNA polymerase, $2 \mu \mathrm{l}$ of the buffer, and $1.5 \mathrm{mM}$ of $\mathrm{MgCl}_{2}$.

The PCR assays for the vanA, $\operatorname{vanB}, \operatorname{aac}\left(6^{\prime}\right)-I e-\operatorname{aph}\left(2^{\prime \prime}\right)-I a$ and ant(6)-Ia genes were performed in a final volume of $20 \mu \mathrm{l}$ containing DNA as template, $0.2 \mu \mathrm{M}$ of each primer, $0.2 \mathrm{mM}$ of dNTPs, $0.5 \mathrm{U}$ of the Taq DNA polymerase, $2 \mu \mathrm{l}$ of the buffer and $1.5 \mathrm{mM}$ of $\mathrm{MgCl}_{2}$.

Amplification products were analyzed by $2 \%$ agarose gel electrophoresis.

\section{RESULTS}

Phenotypic identification of enterococcal isolates to the species level using the BD Phoenix system was verified by the multiplex PCR reaction and confirmed in 34 (97.1\%) out of the 35 analysed isolates, as phenotypic and molecular identification gave discrepant results for the isolate no. E21. The BD Phoenix system identified the isolate as E. faecium, whereas the PCR reaction gave a positive result for the E. faecalis - specific ligase $\left(\mathrm{ddl}_{E \text {.faecalis }}\right)$. Hence, the overall number of enterococcal isolates investigated in the study included 18 isolates of E. faecium and 17 isolates of E. faecalis. The representative results of the molecular identification of the isolates are provided in Table 1 and in Figure 1.

The majority of enterococcal

antibiotic binding site and linked to high-level vancomycin and teicoplanin resistance and vancomycin resistance only, respectively.

Primers used in the molecular analysis were synthesized by Genomed (Poland). Total bacterial DNA was prepared by a rapid lysis method. Briefly, enterococcal colonies grown on the blood agar medium were collected with an inoculation loop and suspended in $150 \mu \mathrm{l}$ of water. The solution was incubated at $95^{\circ} \mathrm{C}$ for 10 minutes, followed by $10 \mathrm{~min}$. incubation in an ultrasonic bath. The solution isolates were isolated from patients hospitalized in the Intensive Care Unit/ICU (12 isolates/34.3\%) and the Internal Medicine Unit/IMU (13 isolates/37.1\%). We observed a greater prevalence of E. faecium compared to E. faecalis in these hospital wards ( 7 vs. 5 isolates and 9 vs. 4 isolates, respectively). E. faecalis was isolated more frequently in other hospital wards, including the Alergology and Lung Diseases, Cardiology, Nephrology and Surgery Units (Table 1). 
Table 2. Primer sequences, amplification conditions and sizes of the relevant PCR products used in the study

\begin{tabular}{|c|c|c|c|c|}
\hline Amplified gene & Primer sequence & $\begin{array}{l}\text { Amplification conditions } \\
\text { (no. of cycles) }\end{array}$ & \begin{tabular}{|c|} 
PCR product \\
size
\end{tabular} & Reference \\
\hline $\mathrm{ddl}_{\text {E. faecalis }}$ & $\begin{array}{l}\text { F: 5'-ATCAAGTACAGTTAGTCT-3' } \\
\text { R: 5'-ACGATTCAAAGCTAACTG-3' }\end{array}$ & \multirow{3}{*}{$\begin{array}{l}\mathrm{PD}: 94^{\circ} \mathrm{C}-5 \mathrm{~min}(1) \\
\mathrm{D}: 94^{\circ} \mathrm{C}-30 \mathrm{sec} ; \\
\text { A: } 50^{\circ} \mathrm{C}-90 \mathrm{sec} ; \\
\mathrm{E}: 72^{\circ} \mathrm{C}-60 \mathrm{sec}(30) \\
\text { FE: } 72^{\circ} \mathrm{C}-10 \mathrm{~min} .(1)\end{array}$} & $941 \mathrm{bp}$ & {$[16]$} \\
\hline ddl $_{\text {E.faecium }}$ & $\begin{array}{l}\text { F: 5'-TAGAGACATTGAATATGCC-3' } \\
\text { R: } 5^{\prime} \text {-TCGAATGTGCTACAATC- } 3^{\prime}\end{array}$ & & $550 \mathrm{bp}$ & [16] \\
\hline $16 S$ & $\begin{array}{l}\text { F: 5'-GACTACCNGGGTATCTAATCC-3' } \\
\text { R: 5'-AGAGTTGATCCTGGCTNAG-3' }\end{array}$ & & $800 \mathrm{bp}$ & [17] \\
\hline $\operatorname{van} A$ & $\begin{array}{l}\text { F: 5'-GGGAAAACGACAATTGC-3' } \\
\text { R: 5'-GTACAATGCGGCCGTTA-3' }\end{array}$ & $\begin{array}{l}\text { PD: } 94^{\circ} \mathrm{C}-2 \mathrm{~min}(1) \\
\text { D: } 94^{\circ} \mathrm{C}-1 \mathrm{~min} ; \\
\text { A: } 50^{\circ} \mathrm{C}-1 \mathrm{~min} ; \\
\mathrm{E}: 72^{\circ} \mathrm{C}-1 \mathrm{~min}(30) \\
\text { FE: } 72^{\circ} \mathrm{C}-10 \mathrm{~min} .(1)\end{array}$ & 732 bp & {$[16]$} \\
\hline $\operatorname{vanB}$ & $\begin{array}{l}\text { F: 5'-ATGGGAAGCCGATAGTC-3' } \\
\text { R: 5'-GATTTCGTTCCTCGACC-3' }\end{array}$ & $\begin{array}{l}\text { PD: } 94^{\circ} \mathrm{C}-3 \mathrm{~min}(1) \\
\mathrm{D}: 94^{\circ} \mathrm{C}-30 \mathrm{sec} ; \\
\text { A: } 54^{\circ} \mathrm{C}-40 \mathrm{sec} ; \\
\mathrm{E}: 72^{\circ} \mathrm{C}-1 \mathrm{~min}(40) \\
\mathrm{FE}: 72^{\circ} \mathrm{C}-10 \mathrm{~min} .(1)\end{array}$ & $635 \mathrm{bp}$ & [16] \\
\hline $\begin{array}{l}\left.\text { aac( } 6^{\prime}\right)-\mathrm{Ie}- \\
\mathrm{aph}\left(2^{\prime \prime}\right)-\mathrm{Ia}\end{array}$ & $\begin{array}{l}\text { F:5'-CAGGAATTTATCGAAAATGGTAGAAAAG-3' } \\
\text { R:5'-CACAATCGACTAAAGAGTACCAATC-3' }\end{array}$ & \multirow{2}{*}{$\begin{array}{l}\text { PD: } 95^{\circ} \mathrm{C}-7 \mathrm{~min}(1) \\
\text { D: } 95^{\circ} \mathrm{C}-1 \mathrm{~min} ; \\
\text { A: } 55^{\circ} \mathrm{C}-1 \mathrm{~min} ; \\
\mathrm{E}: 72^{\circ} \mathrm{C}-1 \mathrm{~min}(33) \\
\mathrm{FE}: 72^{\circ} \mathrm{C}-10 \mathrm{~min} .(1)\end{array}$} & $369 \mathrm{bp}$ & [18] \\
\hline ant(6)-Ia & $\begin{array}{l}\text { F:5'-CGGGAGAATGGGAGACTITG-3' } \\
\text { R:5'-CTGTGGCTCCACAATCTGAT-3' }\end{array}$ & & $563 \mathrm{bp}$ & [19] \\
\hline
\end{tabular}

The predominant site of isolation of the bacteria was blood (27 isolates/77.1\%), followed by urine (6 isolates/17.1\%) and wounds (2 isolates/5.7\%) (Table 1$)$. The frequency of E. faecium and E. faecalis isolation from clinical specimens did not reveal major differences or was even equal. The data is as follows: blood -14 isolates vs. 12 , urine -3 isolates $v s .3$, wounds -1 isolate $v s .1$, respectively.

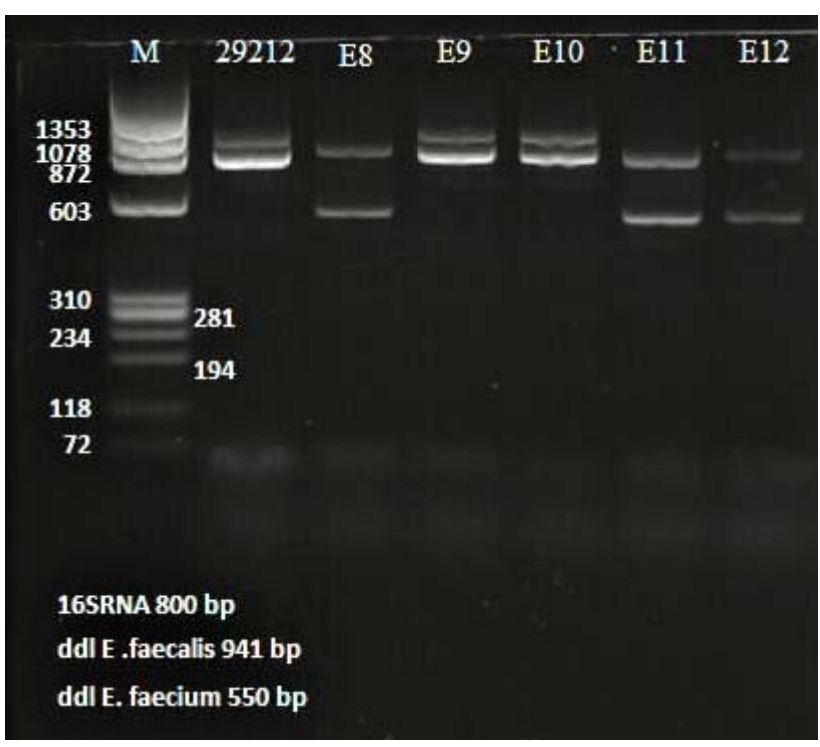

M - ladder; 2912 - reference E. faecalis strain (ATCC 29212); E8, E11, E12 clinical E. faecium isolates; E9, E10 - clinical E. faecalis isolates

Figure 1. Identification of enterococcal isolates analysed in the study using the multiplex PCR assay

\section{Antimicrobial susceptibility testing results}

Phenotypic and genotypic antimicrobial resistance profiles of the analysed isolates are shown in Table 1.

Enterococcal isolates demonstrated the highest rate of resistance against norfloxacin and, consequently, to related fluoroquinolones. As many as $29(82.9 \%)$ isolates were norfloxacin-resistant, including $18(100 \%)$ E. faecium isolates and $11(64.7 \%)$ E. faecalis. According to the EUCAST recommendations, the disc diffusion test with norfloxacin can be used to screen for fluoroquinolone resistance. Ciprofloxacin and levofloxacin susceptibilities can be inferred from the norfloxacin susceptibility. However, there are no clinical breakpoints for Enterococcus spp. and moxifloxacin, which has been used for oral stepdown treatment of endocarditis caused by Enterococcus spp. According to the EUCAST, the norfloxacin disk diffusion test or the moxifloxacin minimum inhibitory concentration (MIC) epidemiological cutoff value (ECOFF) $(1 \mathrm{mg} / \mathrm{L})$ can be used to screen for resistance mechanisms. When screen negative, the isolate should be reported "wild type" or "devoid of fluoroquinolone resistance mechanisms", but not as "susceptible to moxifloxacin".

Aminoglycoside resistance also occurred frequently among the analysed isolates. The HLSR phenotype was detected in $22(62.9 \%)$ isolates, including $12(70.5 \%)$ E. faecalis and 10 $(58.8 \%)$ E. faecium isolates. In all HLSR-positive enterococal isolates, the MIC value for the antibiotic exceeded 1024 $\mathrm{mg} / \mathrm{l}$. The HLGR phenotype occurred in $21(60 \%)$ isolates, including $12(66.6 \%)$ E. faecium and $9(52.9 \%)$ E. faecalis. In all HLGR-positive enterococal isolates, the MIC value for the antibiotic exceeded $256 \mathrm{mg} / \mathrm{l}$. As many as 14 (40\%) isolates were both HLSR and HLGR-positive, including 9 E. faecalis and 5 E. faecium isolates.

The HLAR phenotype detection was subsequently verified by the PCR detection of the ant(6)-Ia and aac(6')Ie-aph(2")-Ia genes encoding for the enzymes involved in the enzymatic modification of streptomycin and gentamicin, respectively (Figure 2).

Twenty out of the 22 HLSR isolates $(90.9 \%)$ and 19 out of the 21 HLGR isolates (90.4\%) were the ant(6)-Ia and $\operatorname{aac}\left(6^{\prime}\right)-I e-\operatorname{aph}(2$ ')-Ia-positive, respectively (Table 1). As mentioned above, $40 \%$ of the HLAR isolates were both HLSR and HLGR - positive, and both resistance genes were detectable in $11(78.5 \%)$ of them.

In the remaining isolates demonstrating HLAR phenotypically, but negative for the corresponding genes in the PCR assay (isolates no. E12, E17, E23, E34), other molecular mechanisms were most probably responsible for aminoglycoside resistance, including another type of enzyme capable of drug modification (HLSR/HLGR) or mutational modification of the 30S ribosomal subunit (HLSR).

Beta-lactam resistance in the analysed isolates was verified in terms of ampicillin- and imipenem resistance. It should be emphasized that $18(100 \%)$ investigated E. faecium isolates were ampicillin resistant, whereas this type resistance was observed in only two $(11.7 \%)$ out of the 17 E. faecalis. According to the EUCAST, ampicillin susceptibility result is tantamount to susceptibility to ampicillin, amoxicillin and piperacillin (with and without beta-lactamase inhibitor). Imipenem resistance was observed in all E. faecium isolates and only one E. faecalis. All isolates resistant to imipenem were simultaneously resistant to ampicillin.

Glycopeptide resistance was detected in a minority $(n=4)$ of the isolates represented alone by E. faecium. The overall 
resistance rate of VRE in E. faecium was $22.2 \%$. The VRE isolates were resistant both to vancomycin and teicoplanin as assessed using the disc diffusion method and E-tests. The MIC values for vancomycin and teicoplanin were $\geq 256 \mathrm{mg} / 1$ and 12-64 mg/l, respectively. The isolates were positive for the vanA gene (Figure 3). Figure 4 summarizes the antibiotic resistance profiles of the analysed E. faecium and E. faecalis isolates.

We identified 19 (54.3\%) MDR isolates, defined by their resistance to at least one drug belonging to at least three distinct groups of antibiotics (Table 1). Fourteen (73.7\%) MDR isolates were cultured from blood, followed by 4 isolates $(21.1 \%)$ cultured from urine and 1 isolate $(5.3 \%)$ cultured from wound. As many as $17(89.5 \%)$ out of the 19 MDR isolates were represented by E. faecium, and three (15.8\%) among them remained susceptible to linezolid alone.

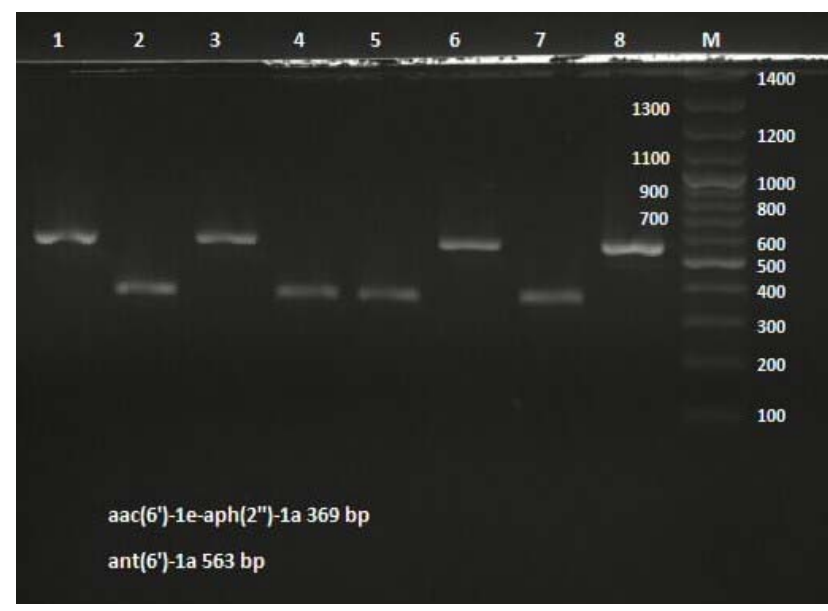

M - ladder; Lanes 1, 3, 6, 8 - ant(6)-Ia - positive isolates; Lanes 2, 4, 5, 7, - $\operatorname{aac}\left(6^{\prime}\right)-a p h\left(2^{\prime \prime}\right)$ - positive isolates

Figure 2. The PCR detection of the ant(6)-Ia and aac(6')-aph(2") genes mediating high-level streptomycin and gentamicin resistance, respectively

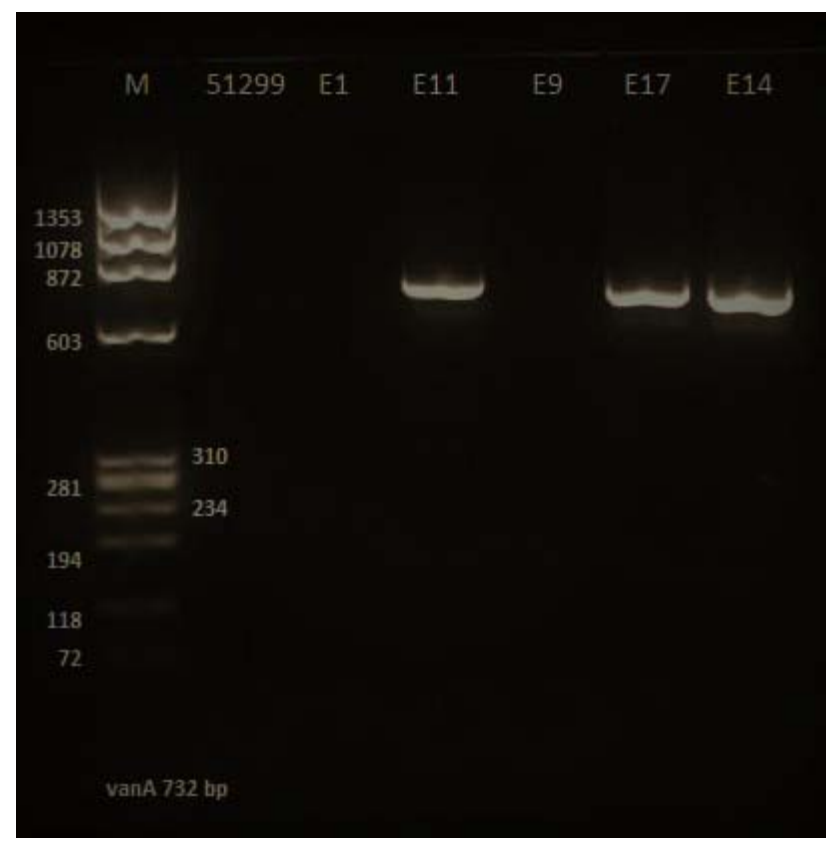

M - ladder; E11, E17, E14 - vanA - positive isolates; E1, E9 - vanA negative isolates

Figure 3. Detection using the PCR of the vanA gene mediating glycopeptide resistance in enterococci

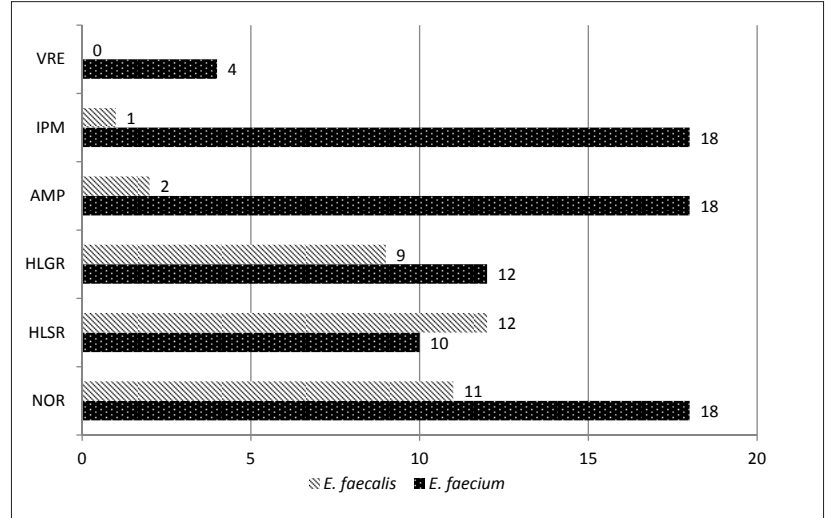

NOR - norfloxacin; HLSR -High Level Streptomycin Resistance; HLGR - High Level Gentamicin Resistance; AMP - ampicillin; IPM - imipenem; VRE vancomycin resistant enterococci

Figure 4. The overall numbers of E. faecalis and E. faecium isolates demonstrating resistance to the tested antimicrobial agents

\section{DISCUSSION}

Our results add further evidence to an increasing problem of antibiotic resistance among enterococci in Polish hospitals, with particular emphasis on MDR E. faecium, which accounted for $94.4 \%$ of the overall number of the analysed isolates belonging to this species. More than $70 \%$ of the patients infected with enterococci included in the study were hospitalized in the ICU and the IMU, and the predominant site $(77 \%)$ of enterococcal isolation was blood. Bacteremia and abdominal infections (which are frequent sources of bacteremia/septicaemia) represent clinical presentations typical for enterococci [14]. The ICU stay, in turn, is considered an important risk factor for enterococcal infections [13,14,20]. Although during a 5-month collection period nearly an equal number of E. faecalis $(\mathrm{n}=17 ; 48.5 \%)$ and E. faecium $(\mathrm{n}=18$; $51.4 \%$ ) was found, we have observed the important role of E. faecium as an etiologic agent of HAIs outcompeting $E$. faecalis in two hospital wards in which we simultaneously observed the highest rate of enterococcal isolation, namely in the ICU and IMU. In spite of E. faecalis predominance in hospitals a few decades ago, recent years have witnessed a significant change in the epidemiology of enterococal infections in the favour of E. faecium [14].

It should be emphasized that all E. faecium isolates included in the study were resistant to ampicillin, imipenem and norfloxacin, which, unfortunately, is not unusual, since according to the epidemiological data and reports of other authors, hospital-associated E. faecium is typically resistant to ampicillin and fluoroquinolones $[1,13,14$, 20-22]. Moreover, 17 out of the 18 isolates demonstrated HLAR, including $27.7 \%$ with the HLSR and $38.8 \%$ with the HLGR; an additional $27.7 \%$ of the isolates were both HLSR and HLGR. HLAR was also common in E. faecalis (HLSR $>70 \%$, HLGR $>50 \%$ ), which is in accordance with previous reports [14]. The average rate of HLAR in Poland (data from 2017) is 53\% for invasive E. faecium and $41 \%$ for E. faecalis [23]. The HLAR phenotype is usually mediated by AMEs, among which the AAC(6')-APH(2')-Ia bifunctional enzyme (encoded by the aac(6')-Ie-aph(2')-Ia gene) with acetyltransferase and phosphotransferase activity is considered predominant [24]. This enzyme modifies 
essentially all clinically available aminoglycosides, except streptomycin, which, in turn, eliminates the therapeutic use of all aminoglycosides other than streptomycin, including their combinations with beta-lactams/glycopeptides. The ANT(6)-I nucleotidyltransferase encoded by the ant(6')Ia frequently mediates HLSR $[18,19]$. The presence of the two genes was confirmed in the overwhelming majority $(90 \%)$ of the HLAR isolates analysed in the study. Interestingly, $40 \%$ of the HLAR isolates $(9 / 52.9 \%$ E. faecalis and $5 / 27.7 \%$ E. faecium) were both HLSR and HLGR - positive, with the two aforementioned resistance genes detectable in $11(78.5 \%)$. The multiple aminoglycoside resistance genes were also frequently harboured by the enterococcal isolates studied by Kobayahi et al. [19], including 37.6\% of E. faecium isolates carrying both the ant(6)-Ia and $\operatorname{aac}\left(6^{\prime}\right)-\operatorname{aph}\left(2^{\prime \prime}\right)$. For the HLAR isolates found in our study to be negative for the ant(6)-Ia or the $\operatorname{aac}\left(6^{\prime}\right)-\operatorname{aph}\left(2^{\prime \prime}\right)$ genes, two possible explanations should be taken into account. They include the possibility of mutation in the location of the primer annealing as reported previously by Vakulenko et al. [18] or the production of a different type of an enzyme capable of drug inactivation (HLSR/HLGR). Of note, alternative enzymes mediating aminoglycoside resistance have been described $[18,19]$. Finally, another plausible mechanism mediating HLSR could be a mutational modification of the 30S ribosomal subunit [19].

The leading conclusion drawn from the results presented above is that there is a limited spectrum of available therapeutic options especially against $E$. faecium. This observation is in line with other reports. In the study of Talaga et al. [13] analysing enterococcal strains from four Polish hospitals, fluoroquinolone resistance ranged between $33.3 \%$ up to $96 \%$. The authors also observed that ampicillin- and vancomycin resistance was demonstrated by all E. faecium isolates from the two hospitals, including $87.3 \%$ of the isolates presenting the HLAR phenotype. Most of the E. faecium isolates were MDR. All E. faecalis isolates, in turn, were susceptible to ampicillin, vancomycin, teicoplanin, linezolid and tygecycline. Data from Poland and other European countries indicate higher mortality rates due to infections caused by E. faecium than E. faecalis, which can be at least partially linked to higher resistance rates observed in this species [14].

Glycopeptides and oxazolidinones, in turn, seemed to be associated with the highest probability of therapeutic success against enterococci in the study presented here. All E. faecium and E. faecalis isolates remained sensitive to linezolid, whereas all E. faecalis and $77.8 \%$ of all E. faecium were susceptible to vancomycin and teicoplanin. Glycopeptide resistance was detected in four (22.2\%) E. faecium isolates and was classified as the VanA phenotype due to the amplification of the vanA gene. Gawryszewska et al. [14] analysed 259 enterococcal isolates collected from 30 hospitals in Poland and also found that all isolates were linezolid sensitive, whereas vancomycin resistance mediated by vanA or vanB was detected in $7.1 \%$ of all E. faecium. Nevertheless, data provided by Talaga-Ćwiertnia et al. [11] indicate that resistance against vancomycin in E. faecium isolates has been on the systematic rise in Poland reaching the rate of $25.2 \%$ in 2016 .
The average rate of invasive vancomycin resistant E. faecium in Poland (data from 2017) is 32\% (28-37\%) and is comparable to the rates observed in Lithuania (36\%), Slovakia (32\%), Hungary (28\%), Romania (34\%), Serbia $(35 \%)$ and Greece (31\%). In the United States and Australia, however, up to $50 \%$ or more of invasive $E$. faecium demonstrate resistance to vancomycin - which poses a severe public health threat [23]. The vanA gene cluster encoding enzymatic machinery altering the terminal peptydoglikan precursor's residues (D-alanyl-D-alanine) critical for antibiotic binding, remains the predominant gene mediating glycopeptide resistance in enterococci $[4,9,11,20,25]$. It is involved in inducible resistance to vancomycin and teicoplanin, and is typically located on transposones (eg, Tn1546) within plasmids $[4,25]$.

It should be mentioned that continuous antibiotic pressure is a driving force towards the selection of new resistance phenotypes, among which one of the most recent threats in the context of enterococcal infections is the emergence of resistance against linezolid. All isolates reported here were linezolid sensitive. This is important information in view of the very disturbing phenomenon associated with a high rate of MDR E. faecium detection. The four vancomycinresistant $E$. faecium isolates were simultaneously resistant to all other tested drugs, with the exception of linezolid. This indicates that oxazolidinones represent an important armamentarium and must be considered the drug of the last resort against many MDR enterococci. Unfortunately, resistance against this group of chemotherapeutics by the inhibition of the elongation of the polypeptide chain in bacterial cells has emerged. This can be mediated by mutations in the $23 \mathrm{~S}$ rRNA gene region and ribosomal proteins (L3 and L4), as well as by the presence of transmissible, plasmid encoded determinants, including the $c f r$ and optrA genes $[4,10]$. Cfr (chloramphenicol-florfenicol resistance) is a methylase able to modify the adenine nucleotide of the $23 \mathrm{~S}$ rRNA, whereas the optrA gene encodes a putative $\mathrm{ABC}$ transporter mediating efflux and is associated with elevated MICs to oxazolidinones in the absence of known 23S rRNA mutations or the $c f r$ gene $[4,15]$.

A significant rise in the number of linezolid resistant enterococci (LRE) has been reported in Polish hospitals since 2012 [15]. Gawryszewska et al. [15] investigated 50 clinical LRE (including E. faecium $-82 \%$ and $E$. faecalis - 16\%) collected between 2008-2015 (20 hospital settings located in 12 Polish cities) and found that the 23S rRNA mutation was the most frequent (94\%) mechanism of linezolid resistance, whereas the optrA gene was identified in two E. faecalis isolates. Krawczyk et al. [9] identified, in addition to the 23S rRNA mutation, the cftr gene in 14 out of the 19 clinical linezolid-resistant $E$. faecium isolates. The detection of transmissible genetic determinants of linezolid resistance such as the optrA and $c f r$, raises concerns about the possible decrease in the effectiveness of linezolid in the future. Moreover, the linezolid-resistant E. faecium showed high prevalence of vancomycin resistance $(90.2 \%)$ in the study of Gawryszewska et al. [15]; similar observations were reported by Krawczyk et al. [9]. It should also be mentioned that over $70 \%$ of LRE investigated by Gawryszewska et al. [15] were isolated from patients of the ICUs and 
haematology wards. In these, the highest use of antimicrobials, including linezolid, is reported. Previous administration of linezolid and treatment with glycopeptides and possibly with carbapenems (imipenems) are considered factors that may favour colonization and subsequent development of infections with LRE [9].

Our study has several limitations, including a limited number of the analyzed isolates and the lack of genetic investigation regarding the clonality of the isolates. Nevertheless, we consider our results a further contribution to the analysis of the epidemiology of the enterococcal HAIs and trends in their antimicrobial resistance. The monitoring of the prevalence and antimicrobial resistance of Enterococcus species is of the uppermost significance to control and prevent infections caused by this group of bacteria.

\section{CONCLUSIONS}

Multidrug-resistance in the hospital-associated enterococci is a disturbing phenomenon, particularly in E. faecium. Understanding of emergent mechanisms of resistance in enterococci can provide insights into the best treatment approaches for these opportunistic pathogens and help to guide physicians in making rational therapeutic decisions. Surveillance of the epidemiologic situation regarding enterococci is crucial to control and prevent infections caused by this group of bacteria.

\section{FUNDING}

No external funding was provided

\section{CONFLICT OF INTEREST}

The authors declare that they have no conflict of interest.

\section{ETHICAL APPROVAL}

The authors declare that ethical approval was not required.

\section{INFORMED CONSENT}

The authors declare that the informed consent was not required.

\section{ORCID iDs}

Agnieszka Bogut (Dhttps://orcid.org/0000-0003-4982-1291

\section{REFERNCES}

1. Sadowy E. Mobile genetic elements beyond the VanB-resistance dissemination among hospital-associated enterococci and other Gram-positive bacteria. Plasmid. 2021;114:102558.

2. Miller WR, Murray BE, Rice LB, Arias CA. Resistance in vancomycin-resistant enterococci. Infect Dis Clin North Am. 2020;34:751-71.

3. Kamińska W, Grochowska M, Chmielarczyk A, Olszewska A, Skolimowska G, Dzierżanowska-Fangrat K. Genetic typing of Enterococcus faecium VRE strains isolated in three hospitals in Warsaw and Siedlce in 2015-2016. Przegl Epidemiol. 2019;73:49-60.

4. Miller WR, Murray BE, Rice LB, Arias CA. Vancomycin-resistant enterococci: Therapeutic challenges in the 21st Century. Infect Dis Clin North Am. 2016;30:415-39.

5. Bender JK, Cattoir V, Hegstad K, Sadowy E, Coque TM, Westh H, Hammerum AM, et al. Update on prevalence and mechanisms of resistance to linezolid, tigecycline and daptomycin in enterococci in Europe: Towards a common nomenclature. Drug Resist Updat. 2018;40:25-39.
6. Fiore E, Van Tyne D, Gilmore MS. Pathogenicity of Enterococci. Microbiol Spectr. 2019;7:10.1128/microbiolspec.GPP3-0053-2018.

7. García-Solache M, Rice LB. The enterococcus: a model of adaptability to its environment. Clin Microbiol Rev. 2019;32: e00058-18.

8. Santajit S, Indrawattana N. Mechanisms of antimicrobial resistance in ESKAPE pathogens. Biomed Res Int. 2016;2016:2475067.

9. Krawczyk B, Wysocka M, Kotłowski R, Bronk M, Michalik M, Samet A. Linezolid-resistant Enterococcus faecium strains isolated from one hospital in Poland - commensals or hospital-adapted pathogens? PLoS One. 2020;15:e0233504.

10. Sadowy E. Linezolid resistance genes and genetic elements enhancing their dissemination in enterococci and streptococci. Plasmid. 2018;99:89-98.

11. Talaga-Ćwiertnia K, Bulanda M. Analysis of the world epidemiological situation among vancomycin-resistant Enterococcus faecium infections and the current situation in Poland. Przegl Epidemiol. 2018;72:3-15.

12. Chmielarczyk A, Pomorska-Wesołowska M, Romaniszyn D, Wójkowska-Mach J. Healthcare-associated laboratory-confirmed bloodstream infections-species diversity and resistance mechanisms, a four-year retrospective laboratory-based study in the south of Poland. Int J Environ Res Public Health. 2021;18:2785.

13. Talaga K, Odrowąż-Konduracka D, Paradowska B, JagiencarzStarzec B, Wolak Z, Bulanda M, Szczypta A. Typing of Enterococcus spp. strains in 4 hospitals in the Małopolska region in Poland. Adv Clin Exp Med. 2018;27:111-7.

14. Gawryszewska I, Żabicka D, Bojarska K, Malinowska K, Hryniewicz W, Sadowy E. Invasive enterococcal infections in Poland: the current epidemiological situation. Eur J Clin Microbiol Infect Dis. 2016;35:847-56.

15. Gawryszewska I, Żabicka D, Hryniewicz W, Sadowy E. Linezolidresistant enterococci in Polish hospitals: species, clonality and determinants of linezolid resistance. Eur J Clin Microbiol Infect Dis. 2017;36:1279-86.

16. Dutka-Malen S, Evers S, Courvalin P. Detection of glycopeptide resistance genotypes and identification to the species level of clinically relevant enterococci by PCR. J Clin Microbiol. 1995;33:24-7.

17. Protocol for PCR amplification of E. faecium and E. faecalis recommended by the EURL-AR. $3^{\text {rd }}$ Version - January 2014. DTU Food National Food Institute. [https://www.eurl-ar.eu/ CustomerData/Files/Folders/21-protocols/281_protocol-forenterococcus-final-vs3.pdf]

18. Vakulenko SB, Donabedian SM, Voskresenskiy AM, Zervos MJ, Lerner SA, Chow JW. Multiplex PCR for detection of aminoglycoside resistance genes in enterococci. Antimicrob Agents Chemother. 2003;47:1423-6.

19. Kobayashi N, Alam M, Nishimoto Y, Urasawa S, Uehara N, Watanabe $\mathrm{N}$. Distribution of aminoglycoside resistance genes in recent clinical isolates of Enterococcus faecalis, Enterococcus faecium and Enterococcus avium. Epidemiol Infect. 2001;126:197-204.

20. Asgin N, Otlu B. Antibiotic resistance and molecular epidemiology of vancomycin-resistant enterococci in a Tertiary Care Hospital in Turkey. Infect Drug Resist. 2020;13:191-8.

21. Haghi F, Lohrasbi V, Zeighami H. High incidence of virulence determinants, aminoglycoside and vancomycin resistance in enterococci isolated from hospitalized patients in Northwest Iran. BMC Infect Dis. 2019;19:744.

22. Jia W, Li G, Wang W. Prevalence and antimicrobial resistance of Enterococcus species: a hospital-based study in China. Int J Environ Res Public Health. 2014;11:3424-42.

23. The Center for Disease, Dynamics Economics \& Policy. Resistance Map: Antibiotic resistance. 2021. [https://resistancemap.cddep.org/ AntibioticResistance.php] Date accessed: July 7, 2021.

24. Shete V, Grover N, Kumar M. Analysis of aminoglycoside modifying enzyme genes responsible for high-level aminoglycoside resistance among enterococcal isolates. J Pathog. 2017;2017:3256952.

25. Gorrie C, Higgs C, Carter G, Stinear TP, Howden B. Genomics of vancomycin-resistant Enterococcus faecium. Microb Genom. 2019;5:e000283. 